Bangladesh J. Plant Taxon. 26(2): 131-148, 2019 (December)

(C) 2019 Bangladesh Association of Plant Taxonomists

\title{
POLLEN MORPHOLOGY OF SECTION CHEIROLEPIS BOISS. OF THE GENUS CENTAUREA L. (ASTERACEAE) IN TURKEY
}

\author{
Burcu Yilmaz Çitak*, Hüseyin Dural, Tuna Uysal and Nur Münevver Pinar ${ }^{1}$ \\ Department of Biology, Faculty of Science, Selcuk University, Konya.
}

Keywords: Centaurea; Cheirolepis; Compositae; Palynomorphology; Numerical analysis; SEM

\begin{abstract}
In this paper, the palynomorphology of 17 taxa of section Cheirolepis in Turkey, were investigated by light (LM) and scanning electron microscope (SEM). Detailed descriptions of the pollen grains were given for each taxon and a well-resolved dendrogram was generated through numerical analysis of palynological diagnostic features. The pollen grains were found to be radially symmetric, isopolar, and generally 3-zonocolporate, with the exception of $C$. derderiifolia, $C$. kotschyi var. floccosa, and $C$. saligna, which were also 4-zonocolporate. The shape of the pollen grains were prolatespheroidal, with the polar axes of 32.76-46.26 $\mu \mathrm{m}$ and equatorial axes of 31.86-45.82 $\mu \mathrm{m}$. The sculpturing of the pollen grains was generally scabrate-perforate or rarely microechinate-perforate. The spines were conical with a changing base length. The length and the width of the spines varied between 0.48 and $2.28 \mu \mathrm{m}$ and 0.4 and $3.39 \mu \mathrm{m}$, respectively. The number of perforations at the base of the spines ranged in two or more rows and they varied between 5 and 30 . The number of spines was $16-70$ in $10 \mu \mathrm{m}^{2}$. The results of this study showed that the polar axes, equatorial axes, aperture type, pollen shape, spine length, perforation number, and number of spines in $10 \mu \mathrm{m}^{2}$ are essential for distinguishing the studied taxa. The taxa were grouped by clustering analysis of selected pollen characters using the UPGMA method.
\end{abstract}

\section{Introduction}

One of the largest tribes of the family Asteraceae (2400 species) is the tribe Cardueae (thistles) with representatives in almost every continent (Barres et al., 2013). The main area of distribution of Cardueae is the Mediterranean region, with the centres of endemism in the eastern and western Mediterranean, the western Irano-Turanian region, and North Africa (Susanna and Garcia-Jacas, 2007). The Cardueae are traditionally subdivided into the four subtribes Echinopinae, Carlininae, Carduinae and Centaureinae (Bentham, 1873; Hoffmann, 1890-94) and this classification is still accepted. Centaurea L. genus is placed in Centaureinae subtribes. Centaureais a relatively large genus in Flora of Turkey, comprised of ca. 250 species distributed across Eurasia, particularly in the Irano-Turanian and Mediterranean region (Anderberg and Elden, 2007). Recently, the number of taxa belonging to the this genus has reached to 201 taxa, of which 112 are endemic in Turkey (Uzunhisarcikli et al., 2007; Uysal et al., 2007; Uysal et al., 2012; Uysal et al., 2017; Uysal and Hamzaoğlu, 2017; Armağan and Uysal, 2018; Sirin et al., 2019) and hence, the endemism rate is about 56\%. The Cheirolepis section of Centaurea is represented by seven taxa in Flora of Turkey and the Checklist of The Flora of Turkey (Wagenitz, 1975; Uysal, 2012; Uysal et al., 2012). Centaurea drabifolia Sm. includes four subspecies and Centaurea kotschyi Boiss. \& Heldr. includes four varieties. The others can be counted as C. derderiifolia Wagenitz, C. deflexa Wagenitz, C. nivea (Bornm.) Wagenitz, C. sericea Wagenitz

*Corresponding author: burcuyilmaz@ selcuk.edu.tr

${ }^{1}$ Department of Biology, Faculty of Science, Ankara University, Ankara 
and C. saligna (C. Koch.) Wagenitz (Uysal et al., 2012). During the last decades, the endemic taxa C. cankiriense Duran \& Dumanand C. glabro-auriculata Uysal \& Demirelma have been described from the same section of Centaurea, and the number of species in Cheirolepis has now been increased to 15 ( Uysal et al., 2007). In flora of Turkey, C. ensiformis P. H. Davis had been evaluated in 'incerta sedis' and C. isaurica Huber-Morath had been written under the title of 'imperfectly known'. However, Ertugrul et al. (2004) has suggested the section of these two taxa as Cheirolepis, according to their morphological and molecular data. With the addition of the last two taxa to section Cheirolepis, the number of section has increased to 17, of which sixare known only by their type locality. All the selected and studied species are endemic in Turkey except $C$. kotschyi var. persica (Boiss.) Wagenitz.

There are several reports on chromosome count for the section Cheirolepis of Centaurea genus (Garcia-Jacas et al., 1997; Romaschenko et al., 2004; Uysal et al., 2009; Uysal et al., 2015). The basic chromosome numbers of section are $x=9, x=11$ with $2 n=18$ and 22. Karyological traits of the studied species except $C$. ensiformis and $C$. glabro-auriculata were reported by the above mentioned researchers. Ten of them were counted as $2 \mathrm{n}=18$. C. kotschyi group were counted as $2 \mathrm{n}=4 \mathrm{x}=36$ (tetraploid), $C$. drabifolia subsp. floccosa (Boiss.) Wagenitz \& Greuter was counted as both $2 \mathrm{n}=4 \mathrm{x}=36$ and $2 \mathrm{n}=6 \mathrm{x}=54$. Chromosome number of $C$. deflexa was counted as $2 \mathrm{n}=6 \mathrm{x}=54$ and those of both $C$. saligna and $C$. sericea as $2 \mathrm{n}=4 \mathrm{x}=36$.

The family Asteraceae has remarkable pollen features that attract researchers due to its systematic importance, since the pioneer work of Wodehouse (1935) to recent studies of Wagenitz, 1955, Stix, 1960; Wagenitz, 1976; Pehlivan, 1995; Pınar and İnceoğlu, 1996; Ozler et al., 2009; Punt and Hoen, 2009; Erkara et al., 2012 and Pınar et al., 2016. Wagenitz (1955) distinguished eight pollen types based on their morphological structures in Serratula, Crupina, Centaurium, Dealbata, Montana, Cyanus, Scabiosa, and Jacea pollen types, where Serratula was recognized as more primitive and Jacea was more evolved. Stix (1960) examined 235 species of Asteraceae from all over the world and determined 45 types, mainly based on the properties of the sexine, and, in particular, of the echinae. Avestisjan (1964) identified five pollen types in Centaurea that are found in/reported from Jacea, Centaurium, Scabiosa, Serratula, and Psephellus' and six pollen types in Jacea that are reported from Sulphurea, Tomentella, Diffusa, Alutaceae, Pergamacea, and Eremopappus. Later on pollen studies have been increased with the availability of different magnification systems, for example Transmission Electron Microscopy (TEM), and new findings, for example establishment of three principal patterns of exine stratification viz., Anthemoid, Helianthoid, and Senecioid, based on different combination of characters, particularly the presence or absence of a large cavea (space) within the pollen wall, and presence or absence of internal foramina (smaller spaces within individual structural elements). Wagenitz (1976) reported that the wealth of other forms of pollen may be explained by the combination of three main trends of evolution: first, is the reduction of the spines, next is the reduction and loss of the inner columellae (with formation of a cavity), and finally, is the formation of a pattern of ridges (lophate or fenestrate pollen). Turkish botanists who have studied the pollen morphology of Centaurea claimed that the pollen shape, exine structure, presence of single- or double-layer columellae, costa thickness, and sculpturing can be useful for the classification of taxa (Pehlivan, 1995; Ozler et al., 2009; Erkara et al., 2012). Punt and Hoen (2009) studied 187 species of Asteraceae16 of which belonged to the genus Centaurea, from northwestern Europe and proposed 37 types of pollen based on the apertures, apocolpium index, exine, cavea, costae, ornamentation, and outlines. They divided the species Centaurea into three pollen types: $C$. scabiosa, $C$. nigra, and $C$. cyanus. Recently, few studieshave been published on section Cheirolepis based on pollen morphology (Hayta et al., 2017; Baser et al., 2019). 
In light of these studies, we studied the pollen morphology of 17 taxa from section Cheirolepis of genus Centaurea from Turkey. With the exception of $C$. saligna, C. kotschyi var. floccosa, $C$. drabifolia subsp. floccosa, and C. derderiifolia the pollen features of the remaining species were examined for the first time in the present study. The aims of this report are to compare pollen characteristics of species with an efficient dendrogram and to clarify the usefulness of these features in terms of systematic implications.

\section{Materials and Methods}

\section{Plant materials}

The plant materials were collected from several localities during their flowering season between 2015 and 2016. Moreover, third author also provided us with his collections. All of the specimens used in this research were stored in the Selçuk University Herbarium (KNYA). The localities, geographical position, altitude, and the voucher number of the specimens are listed in Table 1.

Table 1. Locations and the number of collected samples of Cheirolepis (*endemic species).

\begin{tabular}{|c|c|c|}
\hline Taxa & Location & Voucher number \\
\hline $\begin{array}{l}\text { *entaurea drabifolia } \text { Sm. } \\
\text { subsp. drabifolia }(\mathbf{C 1})\end{array}$ & $\begin{array}{l}\text { A2 Bursa: Uludağ, the summit, above the rocks, } 2100-2200 \mathrm{~m} \text {., } \\
20 \text { August } 2016\end{array}$ & B. Çitak 250 \\
\hline $\begin{array}{l}\text { *C. drabifolia subsp. austro- } \\
\text { occidentalis Wagenitz (C2) }\end{array}$ & $\begin{array}{l}\text { C2 Denizli: Honaz Mountain, The northeast of Babatepe, rocky } \\
\text { places, } 37^{\circ} 41^{\prime} 154^{\prime \prime} \text { N } 29^{\circ} 17^{\prime} 345^{\prime \prime} \text { E, } 2340-2500 \text { m., } 28 \text { July } 2016\end{array}$ & B. Çıtak 218 \\
\hline \multirow{4}{*}{$\begin{array}{l}\text { *C. drabifolia subsp. } \\
\text { floccosa (Boiss.) Wagenitz } \\
\text { \& Greuter (C3) }\end{array}$} & $\begin{array}{l}\text { B5 Kayseri: Pinarbaşı, Şirvan Mountain, roadside, } 2210 \text { m., } 5 \\
\text { August } 2015\end{array}$ & B. Çıtak 177 \\
\hline & $\begin{array}{l}\text { B2 Eskişehir: Between Kütahya-Afyon road, side of road, } \\
39^{\circ} 14^{\prime} 094^{\prime \prime} \text { N, } 30^{\circ} 07^{\prime} 046^{\prime \prime} \text { E, } 1100 \text { m., } 30 \text { June } 2004\end{array}$ & T. Uysal 583 \\
\hline & $\begin{array}{l}\text { C3 Konya: Derebucak, Çamlık Town, Kızıldağ, } 37^{\circ} 21^{\prime} 250^{\prime \prime} \text { N, } \\
31^{\circ} 39^{\prime} 579^{\prime \prime} \text { E, } 1350 \text { m., } 15 \text { June } 2016\end{array}$ & $\begin{array}{l}\text { H. Dural 3566- } \\
\text { B.Çitak }\end{array}$ \\
\hline & $\begin{array}{l}\text { B2 Eskişehir: } 15 \mathrm{~km} \text { from Bozhüyük to Kütahya, side of road, } \\
39^{\circ} 33^{\prime} 400^{\prime \prime} \mathrm{N}, 30^{\circ} 03^{\prime} 842^{\prime \prime} \mathrm{E}, 905 \mathrm{~m} ., 19 \text { June } 2003\end{array}$ & T. Uysal 501 \\
\hline \multirow{4}{*}{$\begin{array}{l}* \text { C. drabifolia subsp. } \\
\text { cappadocica }(\mathrm{DC} .) \\
\text { Wagenitz }(\mathbf{C 4})\end{array}$} & $\begin{array}{l}\text { B6 Sivas: Gürün, between Gürün-Kangal road, Böğrüdelik gate, } \\
38^{\circ} 57^{\prime} 098^{\prime \prime} \mathrm{N}, 37^{\circ} 16^{\prime} 887^{\prime \prime} \mathrm{E}, 1844 \mathrm{~m} ., 14 \text { July } 2015\end{array}$ & B. Çıtak 171 \\
\hline & $\begin{array}{l}\text { C5 Niğde: Bolkar Mountain, Bulgar Mine, 37² } 27^{\prime} 507^{\prime \prime} \mathrm{N} \text {, } \\
34^{\circ} 40^{\prime} 138^{\prime \prime} \text { E, } 1900 \text { m., } 28 \text { July } 2004\end{array}$ & T. Uysal 854 \\
\hline & $\begin{array}{l}\text { C5 Niğde: Ulukışla, Bolkar Mountain, East side of Lake Kara, } \\
\text { west side of Koyunaşağı, rocky places, } 2900 \text { m., } 01 \text { September } \\
2003\end{array}$ & T. Uysal 855 \\
\hline & $\begin{array}{l}\text { C3 Konya: Beyşehir, Doğanhisar-Hüyük road, } 1800 \text { m., } 20 \text { June } \\
2016\end{array}$ & $\begin{array}{l}\text { H. Dural 3573- } \\
\text { B.Çitak }\end{array}$ \\
\hline \multirow[t]{2}{*}{$\begin{array}{l}\text { *C. kotschyi var. kotschyi } \\
\text { (Boiss. \& Heldr.) Hayek } \\
\text { (C5) }\end{array}$} & $\begin{array}{l}\text { C3 Konya: Konya-Beyşehir road, } 1 \mathrm{~km} \text { to Altınapa, droughty } \\
\text { stream bed, under the small trees, } 37^{\circ} 53^{\prime} 011^{\prime \prime} \mathrm{K}, 32^{\circ} 21^{\prime} 668^{\prime \prime} \mathrm{E} \text {, } \\
15 \text { June } 2015\end{array}$ & $\begin{array}{l}\text { H. Dural } 3570 \text { B. } \\
\text { Çitak }\end{array}$ \\
\hline & C4 Karaman: Karadağ, 1600 m., 21.07.2015 & $\begin{array}{l}\text { K. Ertuğrul } 5016 \\
\text { H. Dural }\end{array}$ \\
\hline \multirow[t]{3}{*}{$\begin{array}{l}\text { C. kotschyi var. persica } \\
\text { (Boiss.) Wagenitz (C6) }\end{array}$} & $\begin{array}{l}\text { B5 Kayseri: Pinarbaşı, Şirvan Mountain, around stone pit, } \\
38^{\circ} 39.99^{\prime} \text { N } 36^{\circ} 22.97^{\prime} \text { E, } 1844 \text { m., } 14 \text { July } 2015\end{array}$ & B. Çıtak 169 \\
\hline & $\begin{array}{l}\text { C4 Konya: } 8 \mathrm{~km} \text { from Hadim to Korualan, side of roads, } 1850 \mathrm{~m} \text {., } \\
\text { steppe, } 21 \text { July } 2015\end{array}$ & $\begin{array}{l}\text { K. Ertuğrul } 5006 \\
\text { H. Dural }\end{array}$ \\
\hline & C4 Konya: Hadim, around the Gevne Valley, 1650-1800 m., & K. Ertuğrul 5007 \\
\hline
\end{tabular}




\begin{tabular}{|c|c|c|}
\hline & openings of forest, moving stones, 21 July 2015 & H. Dural \\
\hline & $\begin{array}{l}\text { C4 Konya: Taşkent, } 1 \mathrm{~km} \text { to Beyreli Village, right side of road, } \\
1762 \text { m., } 07 \text { July } 2004\end{array}$ & T. Uysal 696 \\
\hline \multirow[t]{3}{*}{$\begin{array}{l}\text { *C. kotschyi var. decumbens } \\
\text { (C7) }\end{array}$} & $\begin{array}{l}\text { C4 Konya: Taşkent- Alanya, on the tableland, } 9 \mathrm{~km} \text { from Taşkent, } \\
\text { before Belpinar, stony places, } 1800 \mathrm{~m} \text {., } 12 \text { July } 2003\end{array}$ & T. Uysal 508 \\
\hline & $\begin{array}{l}\text { C4 Konya: Bozkır, Sorkun Plateau, before Dikilitaş Plateau, } \\
\text { Sarnıç region, } 1750 \text { m., } 15 \text { July } 2003\end{array}$ & T. Uysal 510 \\
\hline & C4 Konya: Around Tosmur Plateau, 2000-2100 m., 21 July 2015 & $\begin{array}{l}\text { K. Ertuğrul } 5009 \\
\text { H. Dural }\end{array}$ \\
\hline $\begin{array}{l}\text { *C. kotschyi var. floccosa } \\
\text { (C8) }\end{array}$ & $\begin{array}{l}\text { B5 Kayseri: Pinarbaşı, Şirvan Mountain, roadside, } 2210 \text { m., } 05 \\
\text { August } 2015\end{array}$ & B. Çıtak 176 \\
\hline \multirow[t]{2}{*}{$\begin{array}{l}{ }^{*} \text { C. derderiifolia Wagenitz } \\
\text { (C9) }\end{array}$} & $\begin{array}{l}\text { B7 Elazı̆g: Between Elazı ğ-Pertek, } 16 \mathrm{~km} \text { to Pertek, Saklaya } \\
\text { Village, Yukar1 stream region, in vineyard, } 38^{\circ} 46^{\prime} 097^{\prime \prime} \mathrm{N} \text {, } \\
39^{\circ} 12^{\prime} 350^{\prime \prime} \mathrm{E}, 1002 \mathrm{~m} ., 02 \text { August } 2004\end{array}$ & T. Uysal 902 \\
\hline & $\begin{array}{l}\text { B6 Kayseri: Gürün-Divriği road, } 18 \mathrm{~km} \text { to Divriği, small hills of } \\
\text { side of road, } 39^{\circ} 16^{\prime} 53^{\prime \prime} \mathrm{N}, 037^{\circ} 59^{\prime} 27^{\prime \prime} \mathrm{E}, 1500-1600 \mathrm{~m} \text {., } 27 \text { July } \\
2003 \text {. }\end{array}$ & B. Çıtak 172 \\
\hline \multirow[t]{3}{*}{ *C. deflexa Wagenitz (C10) } & $\begin{array}{l}\text { C4 Antalya: Gevne Valley, Küçüklü Village, } 36^{\circ} 49^{\prime} 710^{\prime \prime} \text { N, } \\
32^{\circ} 27^{\prime} 461^{\prime \prime} \text { E, } 1750-1800 \text { m., } 7 \text { July } 2004\end{array}$ & T. Uysal 693 \\
\hline & $\begin{array}{l}\text { C4 Konya: Hadim-Taşkent-Alanya road, } 25 \mathrm{~km} \text { to Taşkent, } \\
\text { steppe,1750-1800 m., } 21 \text { July } 2015\end{array}$ & $\begin{array}{l}\text { K. Ertuğrul } 5011 \\
\text { H. Dural }\end{array}$ \\
\hline & $\begin{array}{l}\text { C4 Konya: Taşkent-Ermenek road, 5-6 km to Başyayla fork, } \\
\text { loamy hills, } 1800 \text { m., } 19 \text { July } 2012\end{array}$ & $\begin{array}{l}\text { K. Ertuğrul-4699- } \\
\text { H. Dural }\end{array}$ \\
\hline $\begin{array}{l}\text { *C. nivea (Bornm.) } \\
\text { Wagenitz (C11) }\end{array}$ & $\begin{array}{l}\text { B3 Eskişehir: } 20 \mathrm{~km} \text { from Mihaliçik to Alpu, the hill with jips, } \\
39^{\circ} 49^{\prime} 592^{\prime \prime} \mathrm{N}, 31^{\circ} 16^{\prime} 890^{\prime \prime} \text { E, } 940 \mathrm{~m} \text {., } 13 \text { June } 2016\end{array}$ & B. Çıtak 182 \\
\hline${ }^{*}$ C. sericea Wagenitz $(\mathbf{C 1 2})$ & $\begin{array}{l}\text { C3 Eskişehir: Bozüyük-Kütahya road, openings of Pinus forest, } \\
1140 \text { m., } 14 \text { July } 2016 .\end{array}$ & $\begin{array}{l}\text { B. Çıtak 207-A. } \\
\text { Ocak }\end{array}$ \\
\hline $\begin{array}{l}\text { *C. cankiriense A. Duran \& } \\
\text { H. Duman }(\mathbf{C 1 3})\end{array}$ & $\begin{array}{l}\text { A4 Çankırı: Atkaracalar-Kalfat road, Ballı Plateau, } 40^{\circ} 44^{\prime} 744^{\prime \prime} \mathrm{N} \text {, } \\
33^{\circ} 05^{\prime} 795^{\prime \prime} \text { E, } 1500 \mathrm{~m} ., 13 \text { July } 2016\end{array}$ & $\begin{array}{l}\text { B. Çıtak 201-B. } \\
\text { Şahin }\end{array}$ \\
\hline \multirow[t]{4}{*}{$\begin{array}{l}* \text { C. saligna (Koch.) } \\
\text { Wagenitz (C14) }\end{array}$} & $\begin{array}{l}\text { C9 Hakkari: Hakkari-Van road, Yüksekova fork, Bağışlar } \\
\text { Village, side of road, droughty stream bed, } 37^{\circ} 72^{\prime} 597^{\prime \prime} \mathrm{N}, \\
44^{\circ} 045^{\prime} 108^{\prime \prime} \text { E, } 1800 \text { m., } 10 \text { July } 2015\end{array}$ & B. Çıtak 168 \\
\hline & $\begin{array}{l}\text { B9 Erzurum: Karayaz1- Göksu road, Göksu Valley, stream bed, } \\
34^{\circ} 39^{\prime} 602^{\prime \prime} \text { N, } 42^{\circ} 08^{\prime} 529^{\prime \prime} \mathrm{E}, 2200 \text { m., } 30 \text { July } 2004\end{array}$ & T. Uysal 891 \\
\hline & $\begin{array}{l}\text { B9 Muss: } 16 \mathrm{~km} \text { to Solhan, } 38^{\circ} 56^{\prime} 380^{\prime \prime} \mathrm{N}, 41^{\circ} 09^{\prime} 016^{\prime \prime} \mathrm{E}, 1660 \mathrm{~m} \text {., } \\
\text { 31 July } 2004\end{array}$ & T. Uysal 897 \\
\hline & $\begin{array}{l}\text { B9 Ağri: Hamur, Buzhane Village, inside the fields, steppe, } 1800 \\
\text { m., } 26 \text { July } 2015\end{array}$ & $\begin{array}{l}\text { K. Ertuğrul } 5117 \\
\text { H. Dural-T. } \\
\text { Uysal }\end{array}$ \\
\hline $\begin{array}{l}\text { *C. glabro-auriculata Uysal } \\
\& \text { Demirelma (C15) }\end{array}$ & $\begin{array}{l}\text { C3 Konya: Derebucak, Kızıldağ, Tekneliyatak region, } 37^{\circ} 20^{\prime} 128^{\prime \prime} \\
\text { N, } 31^{\circ} 29^{\prime} 465^{\prime \prime} \text { E, } 1800-1900 \text { m., } 07 \text { August } 2016 .\end{array}$ & $\begin{array}{l}\text { B. Çıtak 225-H. } \\
\text { Dural-H. } \\
\text { Demirelma }\end{array}$ \\
\hline \multirow[t]{2}{*}{$\begin{array}{l}\text { *C. isaurica Hub.-Mor. } \\
\text { (C16) }\end{array}$} & $\begin{array}{l}\text { C4 Konya: Bozkır, Sorkun Village, Aşağ } 1 \text { Sorkun Plateu, Top of } \\
\text { stony places, } 2000 \text { m., } 13 \text { July } 2003\end{array}$ & T. Uysal 509 \\
\hline & $\begin{array}{l}\text { C4 Konya: Hadim, Between Tosmur Valley and Gevne } \\
\text { Valley,1900-1950 m., } 27 \text { June } 2012\end{array}$ & $\begin{array}{l}\text { K. Ertuğrul } 4638 \\
\text { H. Dural-T. } \\
\text { Uysal }\end{array}$ \\
\hline $\begin{array}{l}{ }^{*} \text { C. ensiformis } \mathrm{P} . \mathrm{H} \text {. Davis } \\
\text { (C17) }\end{array}$ & $\begin{array}{l}\text { C2 Muğla: Köyceğiz, Sandras Mountain, on serpentin places, } \\
1700 \text { m., } 25 \text { July } 2016\end{array}$ & B. Çıtak 193 \\
\hline
\end{tabular}




\section{Palynological analysis}

Both Wodehouse (1935) and Erdtman (1960) techniques were used for the light microscopic investigations. However, the figures were given according to first technique (Figs 2-7). In the first technique, the pollen grains were obtained from mature anthers, stained with glycerin-jelly and safranin, and covered by a coverslip. In the second technique, the anthers were transferred to glass tubes and treated with potassium hydroxide for $20 \mathrm{~min}$. Later, they were mixed in a water bath at $80^{\circ} \mathrm{C}$ and centrifuged at $4500 \mathrm{rpm}$. The supernatant was poured off. The acetolysis solution $(9: 1$, acetic acid: sulfuric acid) was added to glass tubes that were carefully heated and centrifuged again. The acetolysis solution was carefully removed, and the pollen grains were washed and centrifuged again. A solution of 50\% glycerine was added to the tubes, which was then poured out onto filter paper at room temperature. Next, the acetolysed pollen grains were collected from the tubes with a sterile needle and permanent slides were made with glycerine-jelly. All of the pollen slides were photographed using a Leica DM 1000 light microscope, which was attached to a Leica camera. The measurements were made based on 30 or more pollen grains per specimen.

For the scanning electron microscopy (SEM) studies, dried non-acetolysis pollen grains were directly transferred onto aluminum stubs and coated with gold. They were photographed with the SEM at the Advanced Technology Research and Application Centre at the Selçuk University in Konya, and the Turkish Petroleum International Company (TPAO). The pollen terminology was followed of the following literature viz., Wagenitz (1955), Faegri and Iversen (1975), Punt et al. (2007), Punt and Hoen (2009) and Halbritter et al. (2018).

\section{Numerical analysis}

Determined total of twenty qualitative and quantitative pollen characters were recorded. Out of these, eight pollen characters were used to evaluate the taxonomic grouping and similarities among the taxa of Cheirolepis. These characters are listed in Table 2. The mean values of recorded qualitative and quantitative pollen characters were included in the data matrix (Table 2). The Simpson and Roe graphical test (Van der Pluym and Hideux, 1977) was used for the statistical calculations (Fig. 1). For the pollen characters of the 17 taxa, the coefficients of correlation were determined, and they were grouped using the cluster analysis method (UPGMA, dissimilarity, standardized variables). For the multivariate analysis, a primary matrix was created the using 17 taxa and 8 characters. The clustering analysis was based on Gower (1971) sgeneral coefficient similarity (Sneath and Sokal, 1973), which can be used directly with a mixture of character types (binary, qualitative, and quantitative characters). The UPGMA was selected because it is not only the most commonly used method, but it also appears to produce an accurate reflection similarity matrix, as measured by the co-phenetic correlation coefficient of Sokal and Rohlf (1962) and symmetrical hierarchical structure (McNeill, 1979), and has congruence with the classification derived by traditional methods (Ward, 1993). Untransformed, centred, and standardised data were used to create a covariance matrix. MVSP 3.22 software was used for all of the computations.

\section{Results and Discussion \\ Pollen morphology}

The palynological properties of the examined taxa of section Cheirolepis are given in Table 2, and their photographs are shown in Figs 2-7.

\section{Size, symmetry and shape}

The pollen grains of section Cheirolepis were monad, isopolar, and radially symmetrical. The pollen grains of taxa were prolate-spheroidal, with polar axes ranging from 33.77 to $46.26 \mu \mathrm{m}$ and 
equatorial axes ranging from 33.77 to $45.82 \mu \mathrm{m}$. C. cankiriense were found to be smaller, while $C$. ensiformis and C. kotschyi var. kotschyi were larger. Their equatorial view was elliptic and compressed at the poles, while their polar view was circular, with intruding colpi or was slightly triangular with obtuse angles, and the colpi at the sides were amb inter-semiangular (Table 2, Figs $2-7)$.
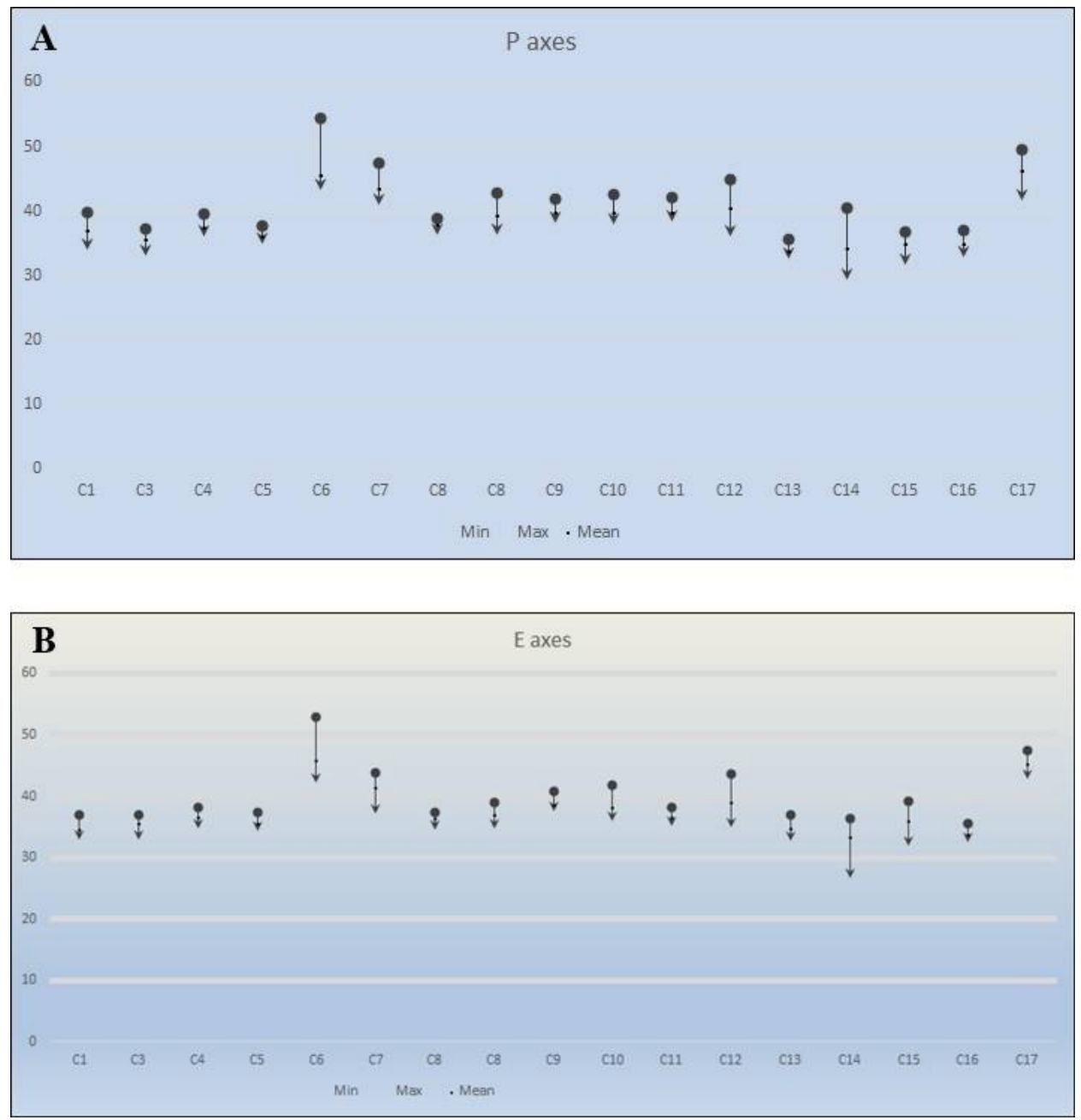

Fig. 1. Simpson and Roe test for the taxa of Cheirolepis. A. Polar axes (P); B. Equatorial axes (E).

\section{Apertures}

The pollen grains of Cheirolepis section were generally 3-zonocolporate or rarely tetracolporate or syncolporate. Some taxa had heteromorphic characteristics. For example, $C$. derderiifolia and $C$. kotschyi var. floccosa had 2\% 4-zonocolporate pollen grains and 98\% 3-zonocolporate pollen grains. The specimens of endemic species $C$. saligna collected from Hakkari and Ağrl provinces had 2\% tetracolporate and $98 \%$ tricolporate pollens, whereas its specimens collected from 

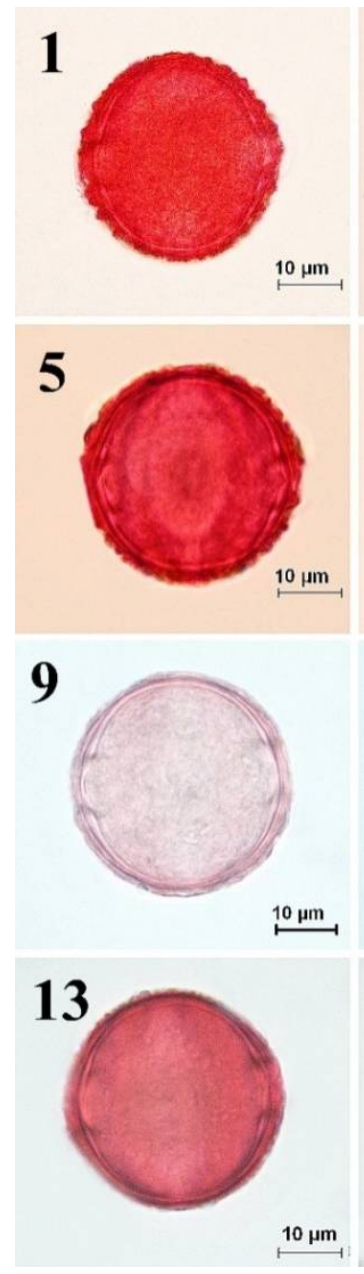
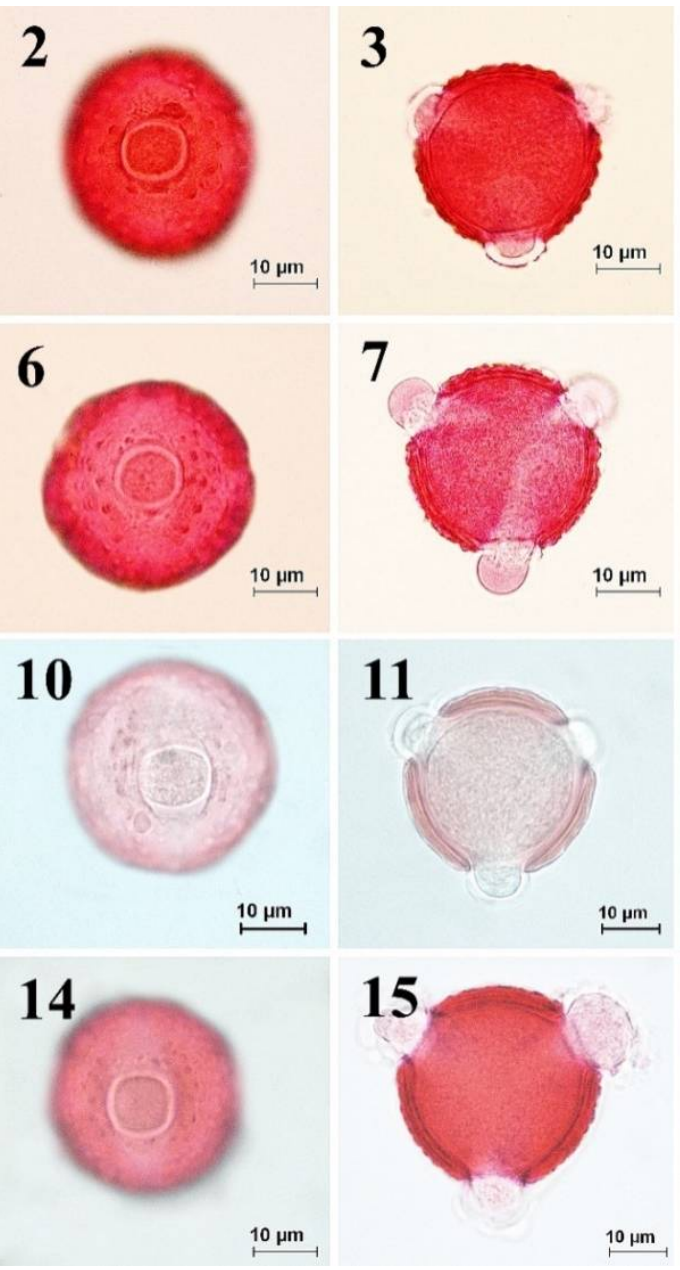

11
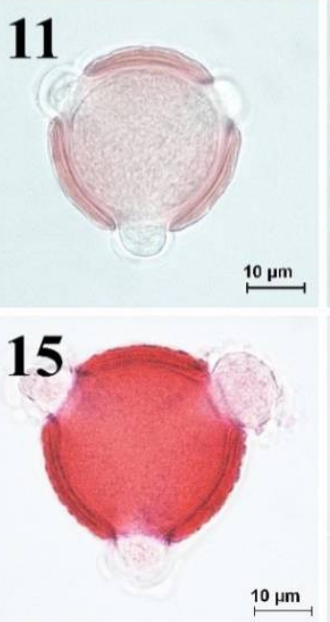
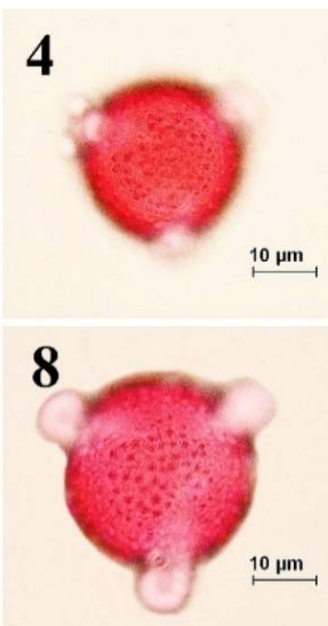

12
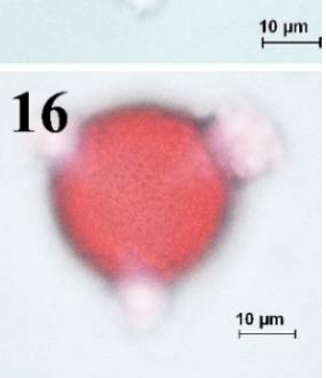

Fig. 2. Pollen morphology of the section Cheirolepis observed under light microscope (LM) according to Wodehouse method. 1-4. C. drabifolia subsp. drabifolia, 5-8. C. drabifolia subsp. austro-occidentalis 912. C. drabifolia subsp. floccosa 13-16. C. drabifolia subsp. cappadocica

Erzurum province had apertures that were $92 \%$ 3-zonocolporate, 5\% syncolporate, and 3\% 4zonocolporate. The colpus was long $(24.39-40.66 \mu \mathrm{m})$ and narrow $(7.23-10.68 \mu \mathrm{m})$ and the ora was circular or lolongate in all of studied species. The highest values were observed in C. kotschyi var. kotschyi, C. ensiformis, C. nivea, $C$. saligna, and C. drabifolia subsp. cappadocica that have the smallest colpus. Margins were distinct, straight and ends were acute to obtuse in all examined taxa. The colpus membrane was granulate in all of the taxa (Table 2, Figs 2-7).

\section{Exine and intine}

The thickness of the exine and intine varied from 1.8 to $3.04 \mu \mathrm{m}$ and 0.73 to $1.18 \mu \mathrm{m}$ when the spines are excluded, respectively. Ectexine wasthicker than endexine without costae and cavea. A large cavea were present in C. deflexa and C. sericea (Fig. 4). The other taxa had a narrow and 

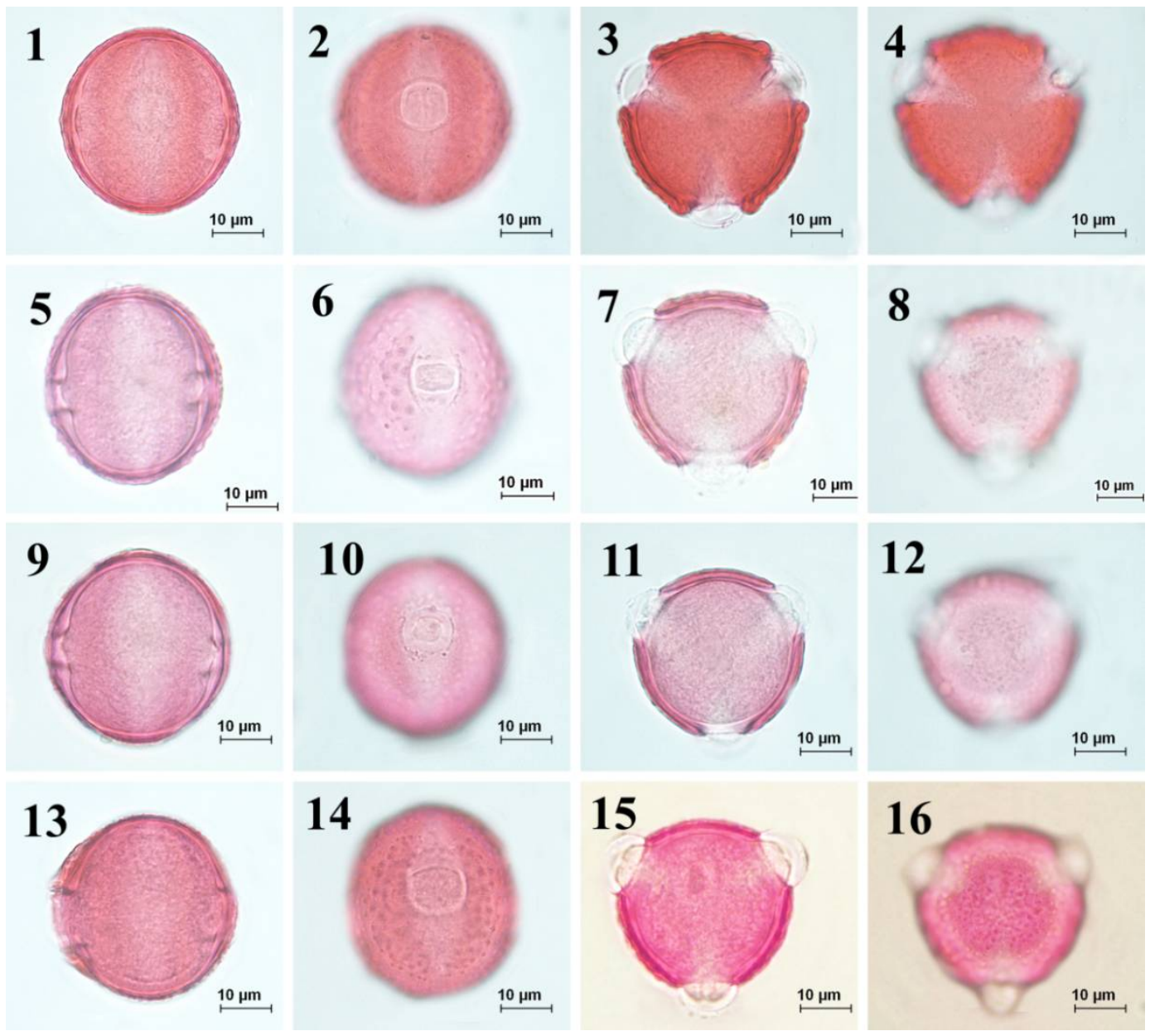

Fig. 3. Pollen morphology of the section Cheirolepis observed underlight microscope (LM) according to Wodehouse method. 1-4. C. kotschyi var. kotschyi, 5-8. C. kotschyi var. persica, 9-12. C. kotschyi var. decumbens, 13-16. C. kotschyi var. floccosa.

bad visible cavea (Figs 2-7). All of the taxa had a costae thickness ranging from $1.5 \mu \mathrm{m}$ to 2.52 $\mu \mathrm{m}$ (Table 2). Intratectal columellae weremore distinct under spines than in inter-spinal region. The spines were commonly conical with a broad basis, the sides were straight or slightly convex and had a subacute tapered apical portion. Of the studied taxa, 13 had a scabrate-perforate ornamentation with spinule lengths of $0.48-0.9 \mu \mathrm{m}$, the remaining had a microechinate-perforate ornamentation with spinule lengths of $1.0-1.19 \mu \mathrm{m}$. The width of the spinules varied between 1.73 (C. drabifolia subsp. floccosa) and $4.45 \mu \mathrm{m}$ (C. drabifolia subsp. austro-occidentalis), while the base of the spinules in almost all of the studied species was irregular 1,2, or 3 seriate with holes of equal size. The number of perforations was 5-10, 15-20, 20-25, 25-30, and 35-50. The distance between 2 spinules was $0.28-3.39 \mu \mathrm{m}$ and there were 5-70 spinules in $10 \mu \mathrm{m}^{2}$ (Table 2, Figs 2-7). 

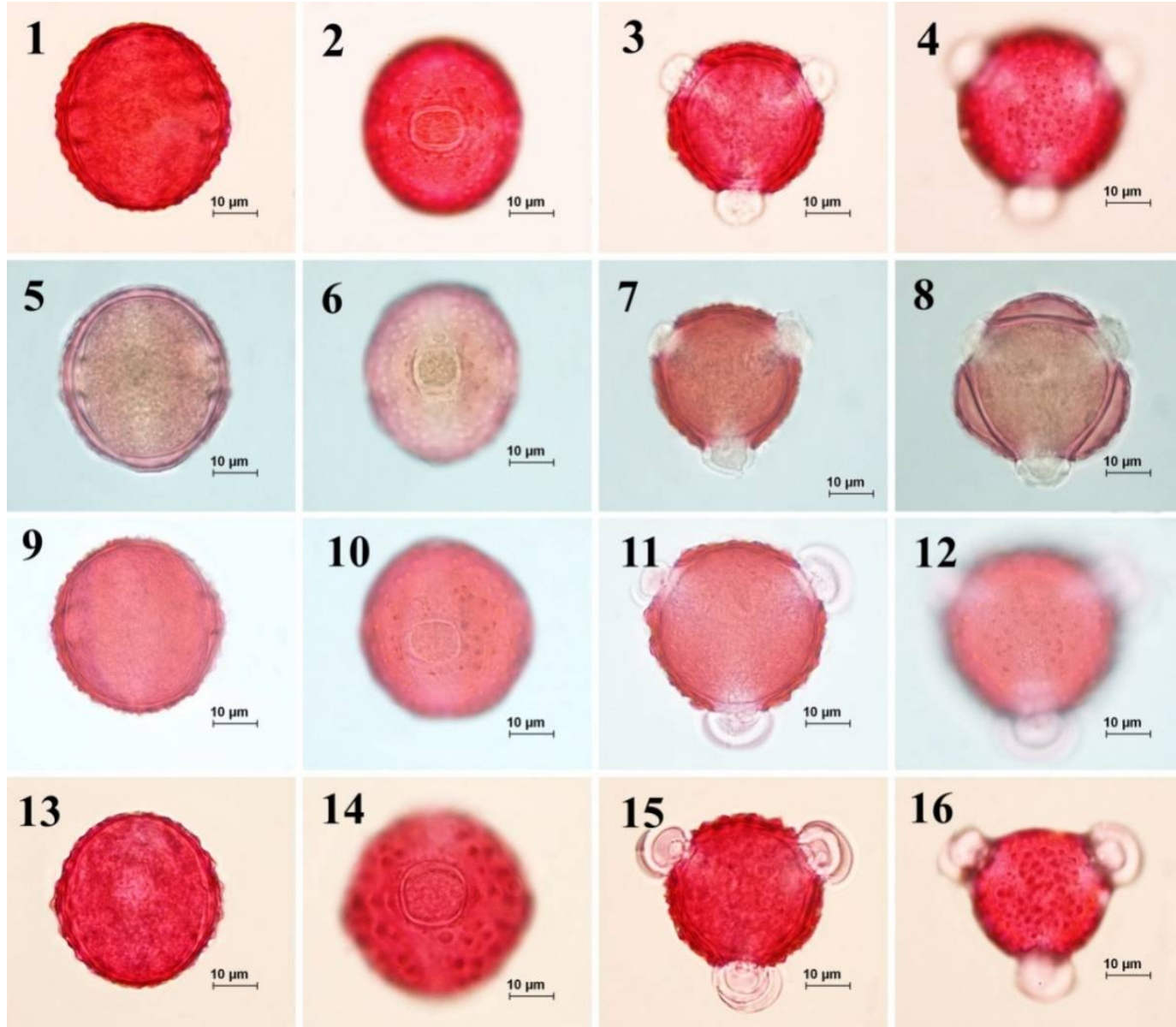

Fig. 4. Pollen morphology of the section Cheirolepis observed underlight microscope (LM) according to Wodehouse method. 1-4. C. nivea, 5-8. C. sericea, 9-12. C. deflexa, 13-16. C. cankiriense.

\section{Numerical analysis of the pollen character states}

The dendrogram obtained from the cluster analysis using the UPGMA was based on the eight palynological variables viz. polar axes/equatorial axes, the length of spines, number of spins, costae, cavea, apocolpium, amb, and perforation number at base of 17Centaurea taxa and is presented in Fig. 8. This dendrogram shows the similarities among the taxa being investigated. The dendrogram revealed two main groups with a 54\% similarity; the first one contained $C$. sericea and $C$. deflexa, which are local and very distinct species with the similar appendage structure in section Cheirolepis, and the second one comprised the other 15 taxa. The second group, which consisted of two main clusters, recognized as Cluster A and Cluster B. Cluster A includes $C$. ensiformis, C. cankiriense, and $C$. drabifolia subsp. drabifolia with a similarity rate of 69\%. Cluster B includes 12 taxa with three subgroups, namely B1, B2, and B3. Cluster B1 contained only $C$. derderiifolia, which is a huge and distinctive species without close relatives in section Cheirolepis. Cluster B2 included C. kotschyi and its varieties. Cluster B3 also included two subgroups, namely B3a and B3b. Cluster B3a also included two subclusters which contained $C$. 
isaurica C. saligna, C. nivea and C. glabro-auriculata with a similarity rate of $83 \%$. Cluster B3b included C. drabifolia subsp. cappadocica, C. drabifolia subsp. floccosa and, C. drabifolia subsp. austro-occidentalis subspecies, with a similarity rate of $83 \%$.

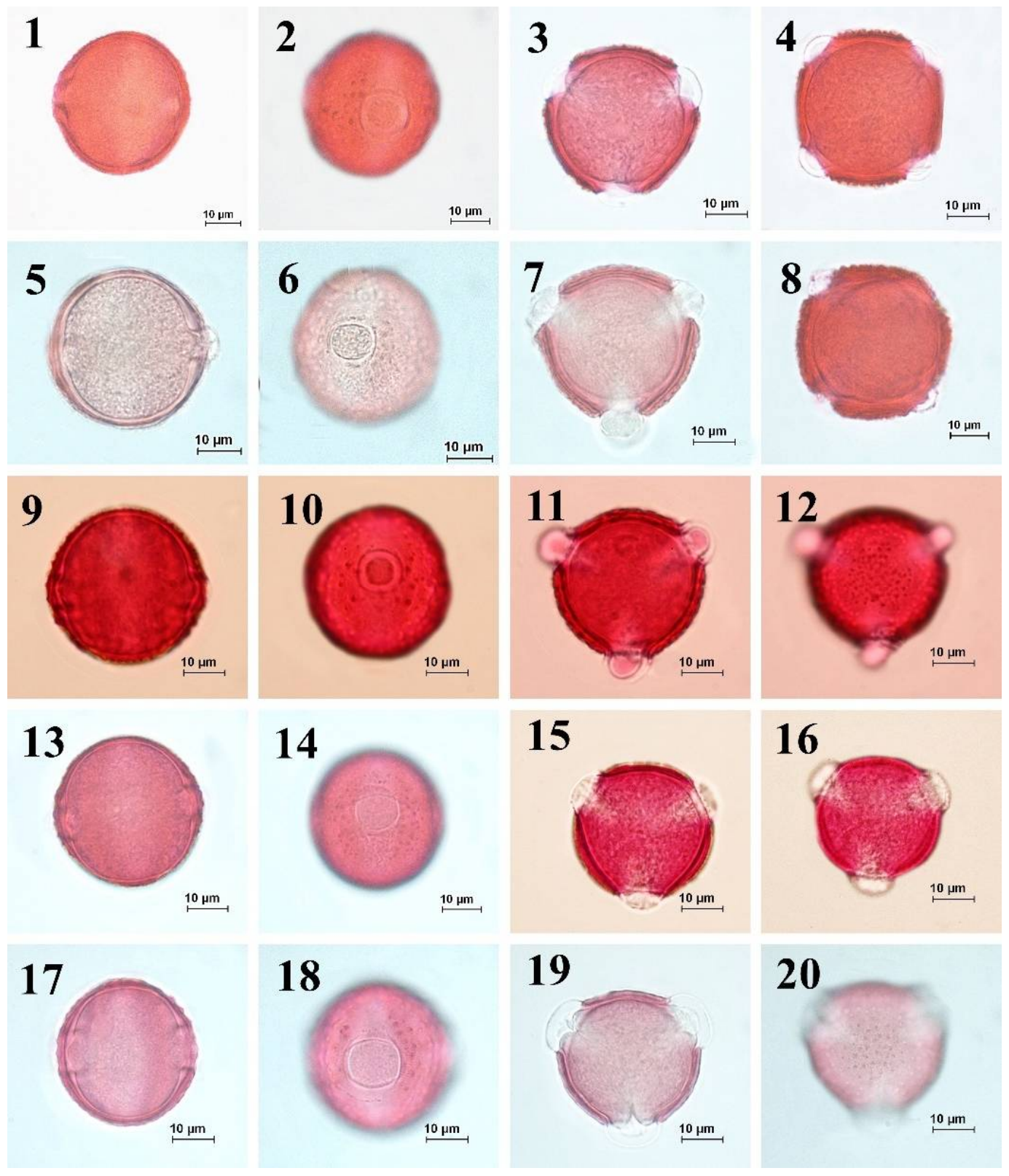

Fig. 5. Pollen morphology of the section Cheirolepis observed underlight microscope (LM) according to Wodehouse method. 1-4. C. derderiifolia, 5-8. C. saligna, 9-12. C. glabro-auriculata, 13-16. C. isaurica 17-20. C. ensiformis. 
The pollen morphology of Cheirolepis section taxa show taxonomically significant characters. The main differences have been found at the species level.The pollen grains of the Centaurea taxa can be classified as Centaurium, Dealbata, Montana, Cyanus, Scabiosa, or Jacea types, according to Wagenitz (1955), Centaurea type according to Stix (1960) and Centaurea nigra L., C. scabiosa L., or C. cyanus L. types according to Punt and Hoen (2009). Pollen shape was prolate-spheroidal in Cheirolepis. The examined species pollen grains were determined as Jacea pollen type, which, despite a very diverse habit and morphology, was found to be monophyletic in a large group according to Wagenitz (1955) as indicated before Hayta et al. (2017). The fifteen species which were had narrow cavea placed into Centaurea nigra pollentype, and $C$. sericea and $C$. deflexa which had broad cavea placed into Centaurea scabiosa pollen type according to Punt and Hoen (2009, Figs 2-7).
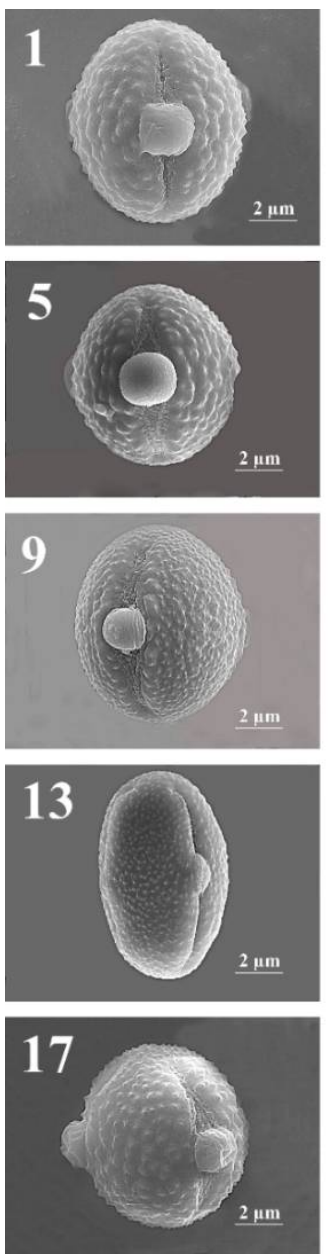
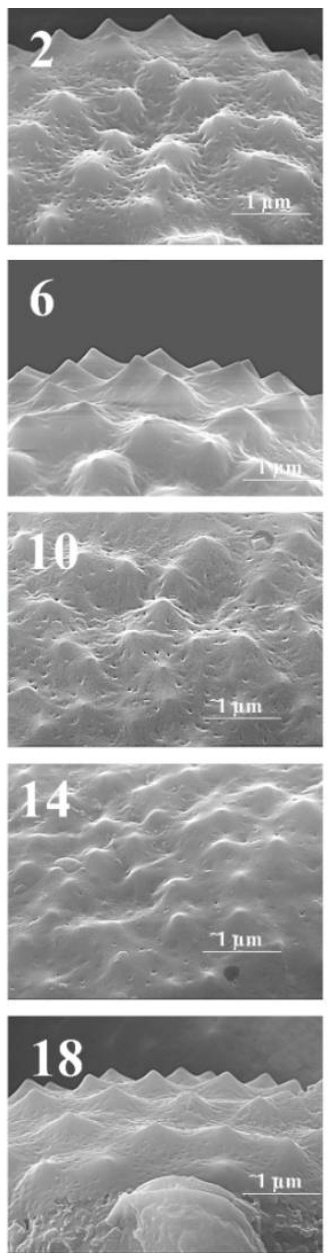
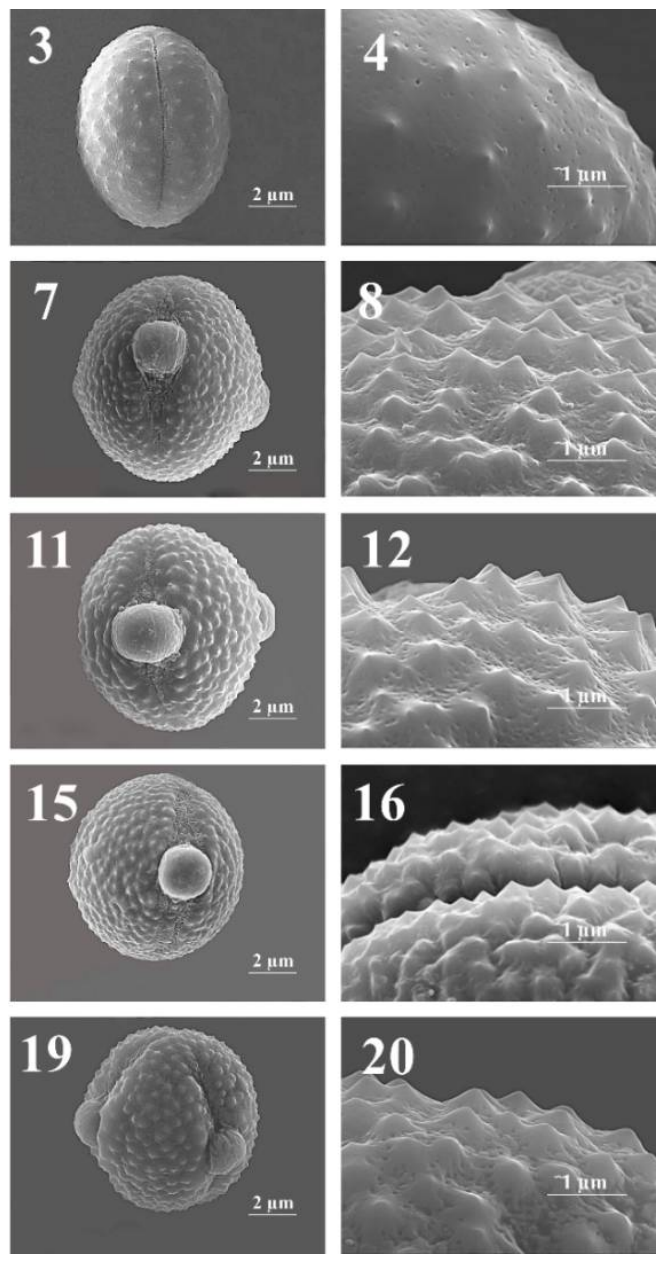

Fig. 6. Scanning electron microscope (SEM) images on the pollen grains of Cheirolepis section. 1-2. Centaurea drabifolia subsp. drabifolia, 3-4. C. drabifolia subsp. austro-occidentalis, 5-6: C. drabifolia subsp. floccosa, 7-8. C. drabifolia subsp. cappadocica, 9-10. C. kotschyi var. kotschyi, 11-12. C. kotschyi var. persica, 13-14. C. kotschyi var. decumbens, 15-16. C. kotschyi var. floccosa, 17-18. C. nivea, 19-20. C. sericea. 

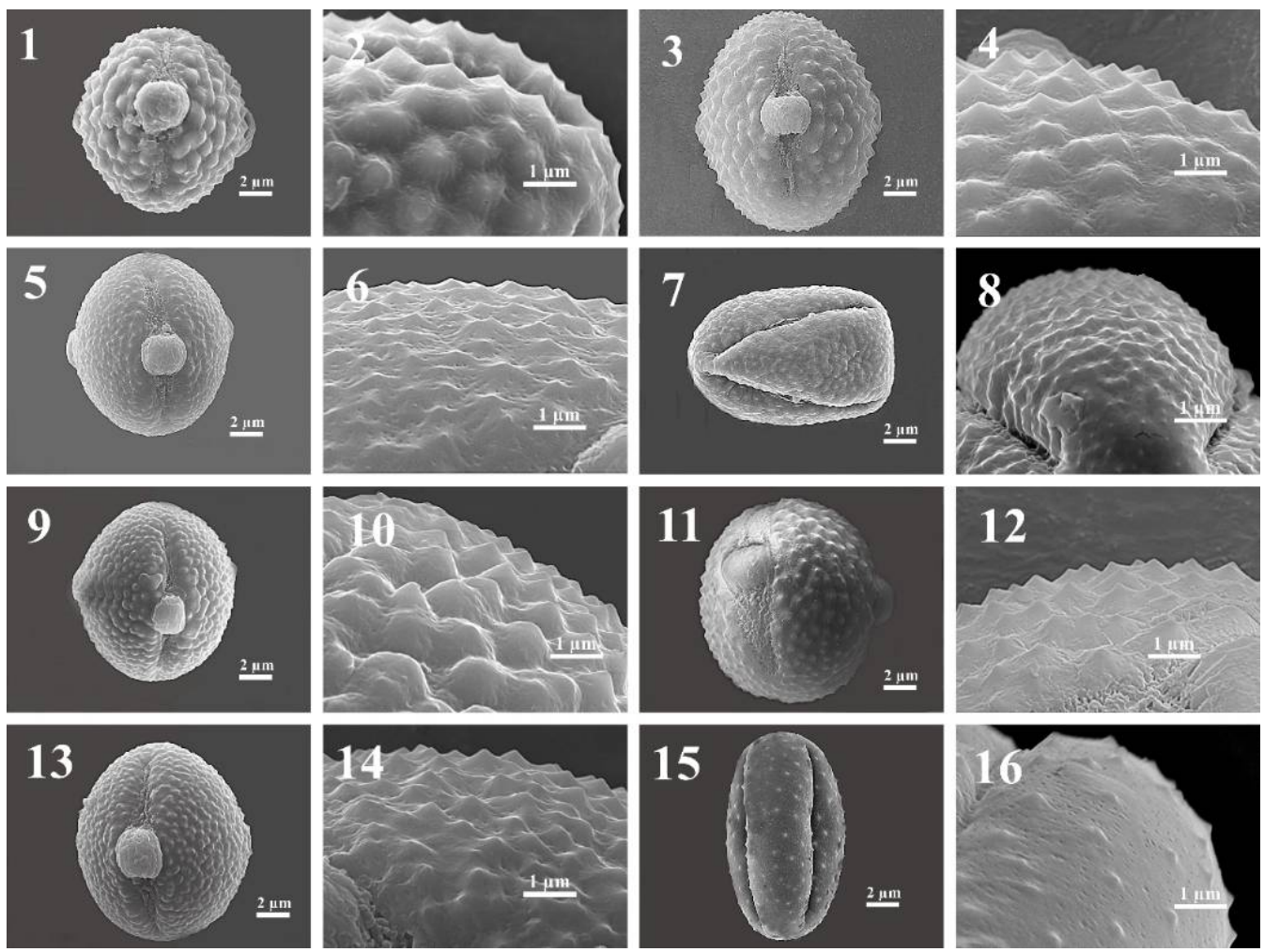

Fig. 7. Scanning electron microscope (SEM) images on the pollen grains of Cheirolepis, Pteracantha, Pseudoseridia and Cheirolepis-Pseudoseridia sections. 1-2. Centaurea deflexa, 3-4. C. cankiriense, 5-6. C. derderiifolia, 7-8. C. saligna (T. Uysal-891), 9-10. C. saligna (B. Çıtak-168), 11-12. C. glabroauriculata, 13-14. C. isaurica, 15-16. C. ensiformis.

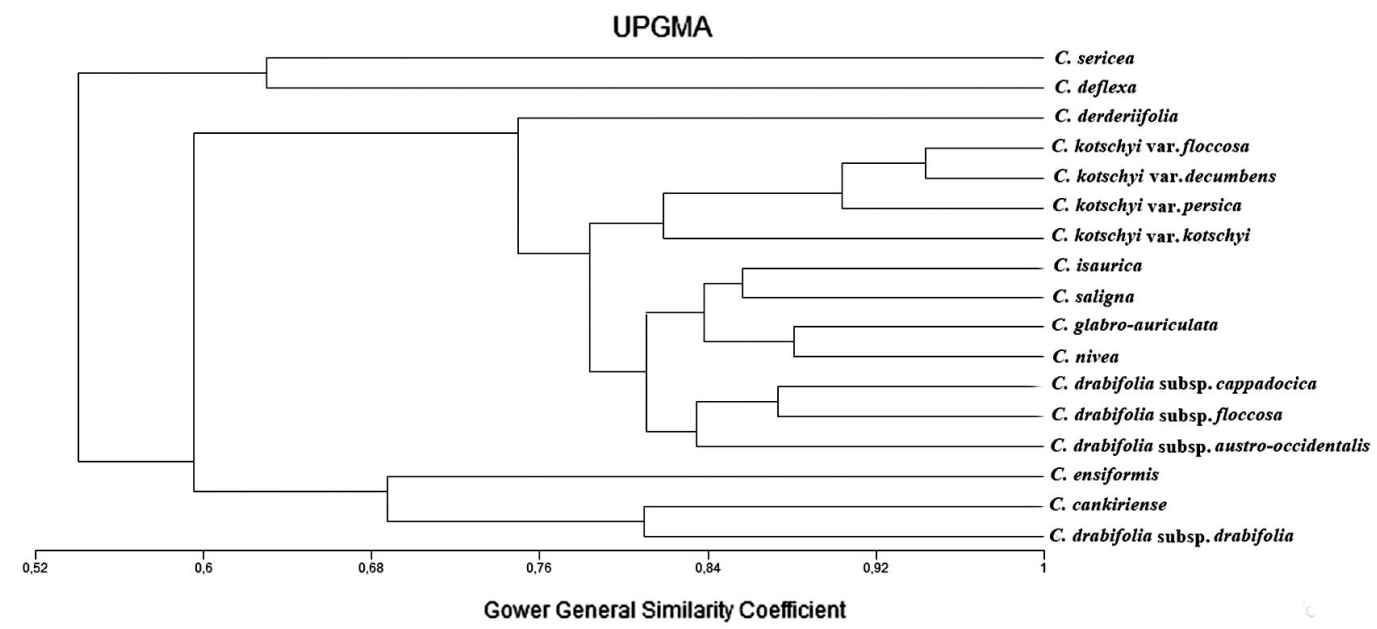

Fig. 8. Dendrogram based on pollen morphology of the examined taxa of Cheirolepis sectionindicating dissimilarity distance. 


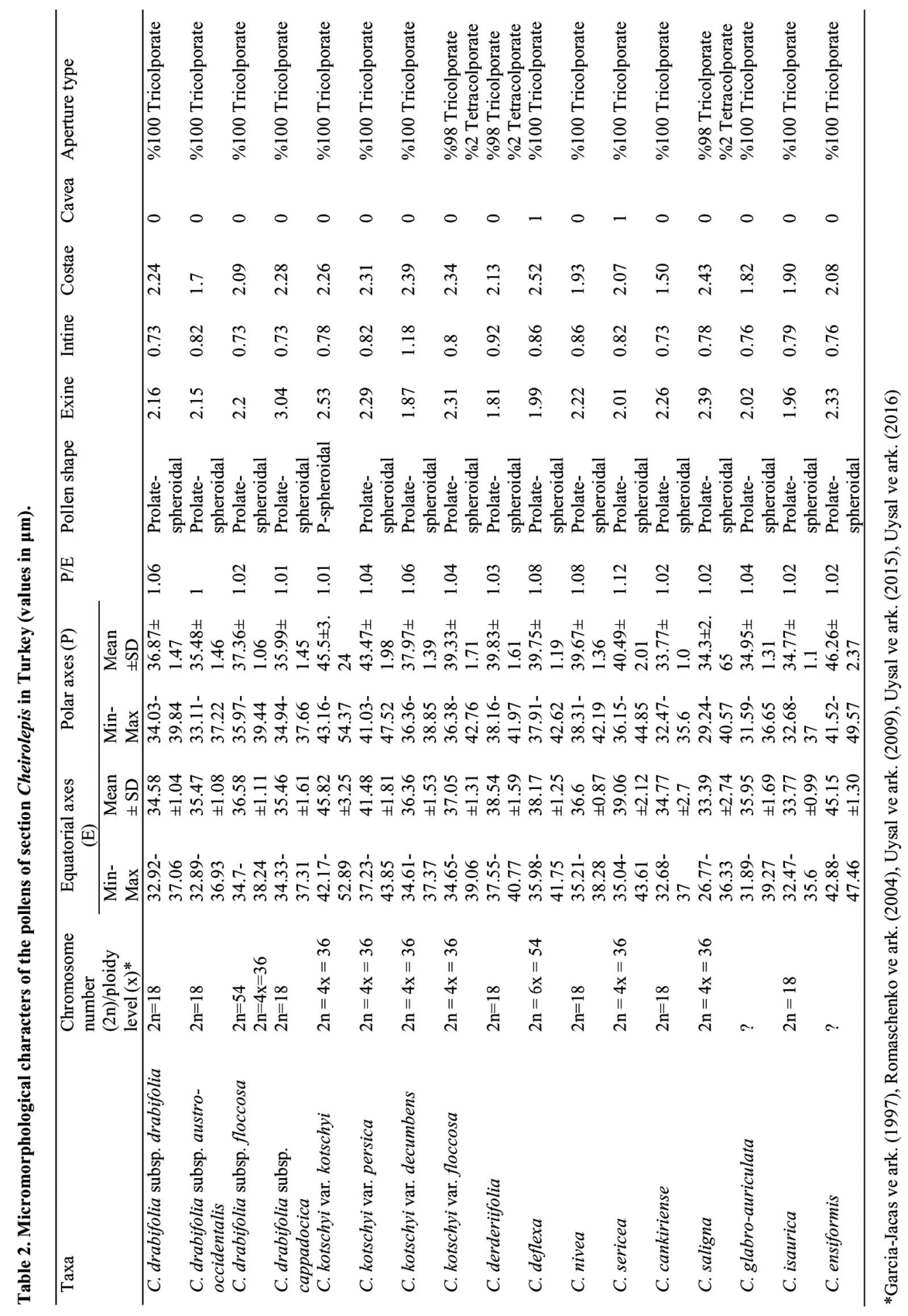


䂧

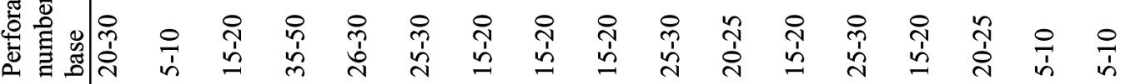
뉴용

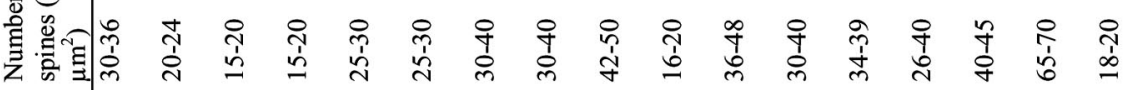

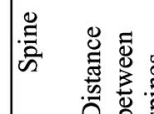

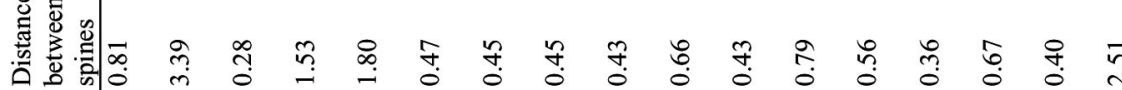
责雚

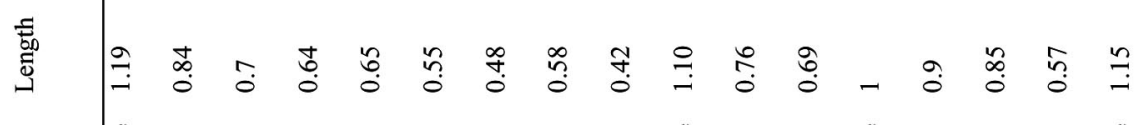

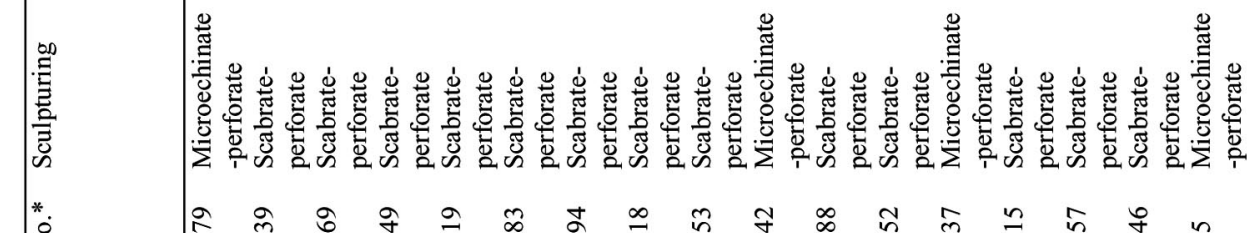

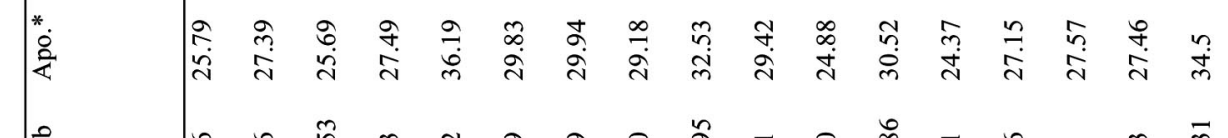

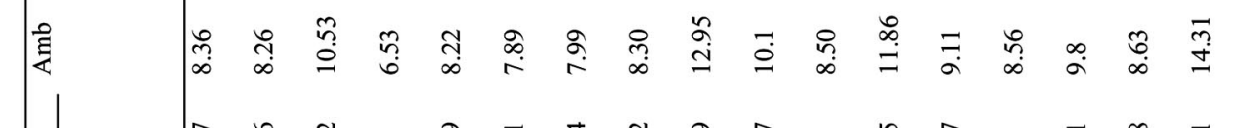

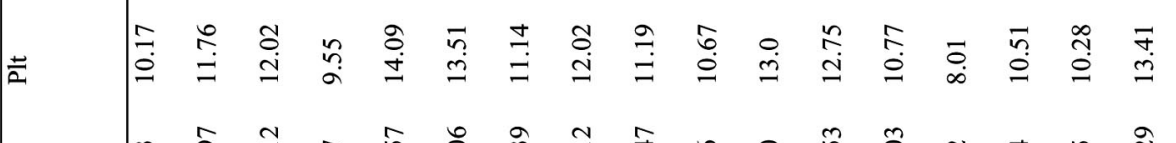

䒺

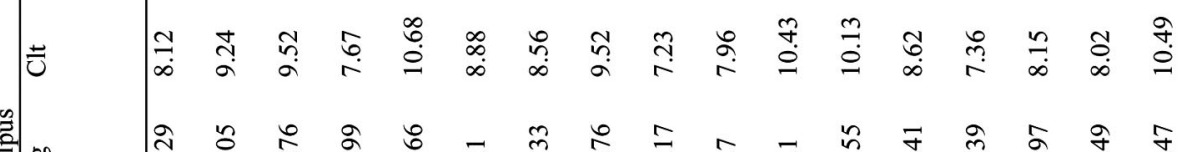

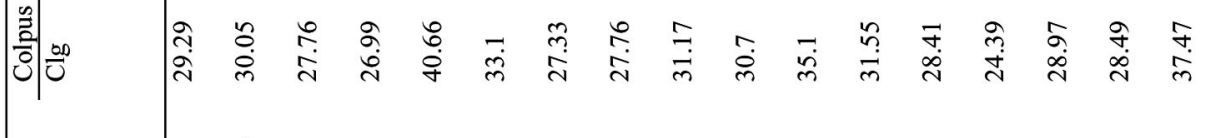



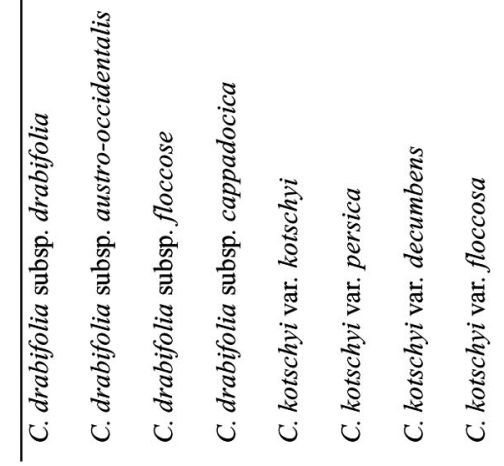

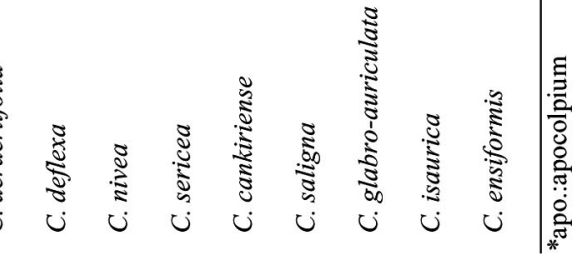


The chromosome number of the members of Cheirolepis section have been determined as $2 \mathrm{n}=18,2 \mathrm{n}=36$ or $2 \mathrm{n}=54$ (Garcia-Jacas et al., 1997; Romaschenko et al., 2004; Uysal et al., 2009; Uysal et al., 2015). With the present study we confirm that the heteromorphy in apertural system of Cheirolepis and the presence of cavea reflects chromosomal variation in C. saligna, C. deflexa and C. sericea (Table 2, Fig. 4). However, the other polyploid taxa does not have such a state.

Chaturvedi et al. (1990)and Brochmann (1992) reported that the size of the pollen grains strongly correlates with the level of polyploidy, however, the data obtained herein does not show such a correlation. The mean values for the $\mathrm{P}$ and $\mathrm{E}$ in diploid and polyploidy species are very similar (Table 2, Figs 2-7). Similarly, a great variation of $\mathrm{P}$ and $\mathrm{E}$ in diploid, triploid and tetraploid species of Tripleurospermum Schultz, Carl (Karl) Hein. and Matricaria L. were not observed by Ceter et al. (2013).

The subapical perforations in the spinules or spine bases in the family Asteraceae are a wellspecified taxonomic character for distinguishing the taxa (Mesfin et al., 1995; Ceter et al., 2013; Pinar et al., 2016) . Moreover, according to Wagenitz (1976), the reduction of the spine is a progressive characteristic for Asteraceae. The number of spines varies from species to species in Cheirolepis. The smallest spines were found in C. kotschyi var. decumbens, while the biggest were found in $C$. derderiifolia. Although the number of perforations were different, the present paper has shown that the size of the perforations was similar in each taxa. In parallel, some researchers have claimed that the ornamentations between the spines are important pollen characters in Asteraceae (Mesfin et al., 1995; Ceter et al., 2013). However, we found only the perforate ornamentation between the spinesas useful pollen traits.

According to Kaya (1986), Özler et al. (2009) and Hayta et al. (2017) C. drabifolia subsp. floccosa, C. kotschyi var. floccosa, and $C$. derderiifolia have a reduction in their spine length which is evaluated as an advanced pollen character in Centaurea. The present study supports this observation.

Among the studied taxa, 14 of them had 3-zonocolporate aperture. However, C. kotschyi var. floccosa had 98\% 3-zonocolporate and 2\% 4-zonocolporate apertures. Kaya (1986) studied the pollen morphology of $C$. derderiifolia and $C$. saligna and claimed a tricolporate aperture, spheroidal, suboblate pollen shape, $38.61 \pm 2.22 \mu \mathrm{m}$ equatorial axes, and $38.6 \pm 2.11 \mu \mathrm{m}$ polar axes in $C$. derderiifolia, as well as a $40.45 \pm 1.88 \mu \mathrm{m}$ equatorial axes and $41.06 \pm 1.83 \mu \mathrm{m}$ polar axes in $C$. saligna. The examined species had a similar narrow colpus and distinct porus. In our study, the species C. saligna collected from the Hakkari (B. Çıtak-168) and Ağrı (K. Ertuğrul-5117-H. Dural $\&$ T. Uysal) provinces showed apertures that were $98 \%$ tricolporate and $2 \%$ tetracolporate (Fig. 7). The apertures of the specimens, collected from the type locality of $C$. saligna (Erzurum province, T. Uysal-891), were mostly tricolporate (92\%), which was followed by syncolporate (5\%) and tetracolporate (3\%) ones (Fig. 7). Similarly, the apertures observed in C. derderiifolia were mostly tricolporate (98\%) and a few tetracolporate (2\%, Fig. 7). The other observations of Kaya (1986) overlap with our records.

The UPGMA dendrogram based on pollen morphological characteristics has been discriminated against the species of Cheirolepis. The positions and groupings of the species of Cheirolepis reflected as the clusters in the dendrogram were found to be agreeable with the classification made earlier on a large scale (Fig. 8). However, C. drabifolia subsp. drabifolia positioned in different subclade has raised the question of whether new taxonomic delimitation of these taxa are required or not. From the findings of the pollen analysis, we could affirm that there was a significant correlation between the previous taxonomical classifications. 


\section{Conclusions}

The pollen morphology of 17 species of section Cheirolepis were observed bylight microscopy and SEM, and among the palynological characters, the pollen size and spine length were determined as the most useful for the systematics of genus Centaurea. The pollen size and spine characteristics has been proved to be the most useful characters of systematic value in section Cheirolepis. The Jacea pollen type determined for this section based on Wagenitz's pollen types is more evolved one. The cluster analysis revealed that the taxa could be divided into three main groups according to the pollen morphology. The polar axes, equatorial axes, spine length, apocolpium, amb, the presence of cavea, costae, and number of spines are the most important characters to explain the variations among the taxa studied. Different aperture types, and spine size and density among the taxa could be associated with their different dispersal mechanisms or germination requirements, which may have arisen as a result of an evolutionary adaptation independently of different habitat types or microclimatic areas, especially for the endemics. The systematic problems of the section of Cheirolepis can be solved more precisely by the combination ofanatomical, macro- and micromorphological and molecular data.

\section{Acknowledgements}

We would like to thank Dr. Kuddisi Ertuğrul, Dr. Atila Ocak, Dr. Hakkı Demirelma, Dr. Bilal Şahin, and Dr. Ersin Karabacak for their valuable field work, as well as Dr. Makra Laszlo (Szeged University, Hungary) for his most valuable advice and for checking our manuscript, and finally, the Selçuk University Scientific Research Unit for their financial support (Project number: 15101010).

\section{References}

Anderberg, A.A. and Elden, P. 2007. Tribe Inuleae Cass. In:Kadereit J.W. and Jeffrey C. (Eds.), The families and genera of flowering plants. Springer, Berlin, pp. 374-391.

Armağan, M. and Uysal, T. 2018. Centaurea kirmacii (Asteraceae), a new species from southwestern Anatolia, Turkey. Phytotaxa 362: 233-238.

Avestisjan, E.M. 1964. Palynosystematique de la tribu des Centaureinae des Asteraceae. Trudy Botanicheskogo Instituta Akademii Nauk Armjanskoi SSR 14: 31-47.

Barres, L., Sanmartín, I., Anderson, C.L., Susanna, A., Buerki, S., Galbany-Casals, M. and Vilatersana, R. 2013. Reconstructing the evolution and biogeographic history of tribe Cardueae (Compositae). American Journal of Botany 100: 867-882.

Baser, B., Hayta, Ş., Doğan, G., Çelik, S.D.Y. and Aksoy, H.S. 2019. Micromorphological study of Centaurea L. (Asteraceae); some taxa of eight sections analysed with scanning electron microscopy and light microscopy. Biologia 74: 583-597.

Bentham, G. 1873. Compositae.In: Bentham, G. and Hooker, J.D. (Eds.), Genera plantarum 2. London. pp. $163-533$.

Brochmann, C. 1992. Pollen and seed morphology of Nordic Draba (Brassicaceae): phylogenetic and ecological implications. Nordic Journal of Botany 12: 657-673.

Chaturvedi, M., Yunus, D. and Nair, P.K.K. 1990. Cytopalynological studies of Arachis (Leguminosae) cultivated and wild species and their hybrids. Grana 29: 109-117.

Ceter, T., Pınar, N.M., İnceer, H., Hayirlioğlu-Ayaz, S. and Yaprak, A.E. 2013. The comparative pollen morphology of genera Matricaria L. and Tripleurospemum Sch. Bip. (Asteraceae) in Turkey. Plant Syst Evol 299: 959-977.

Erdtman, G. 1960. The acetolysis method-a revised description. Sven Bot Tidskr 54: 516-564. 
Erkara, İ.P., Köse, Y.B., Osoydan, K. and Yücel, E. 2012. Pollen morphology of some endemic Turkish Centaurea L.(Asteraceae, section Phaloletis) and their taxonomic value. Plant Syst Evol 298: 11111117.

Ertugrul, K., Uysal, T., Garcia-jacas, N., Susanna, A. and Garnatje, T. 2004. The systematic position of Centaurea ensiformis and Centaurea isaurica from Turkey and the evolution of some characters in Centaurea. Isr J Plant Sci52: 257-263.

Faegri, K. and Iversen, J. 1975. Textbook of pollen analysis. Scandinavian University Books, Copenhagen. pp. 294

Garcia-Jacas, N., Susanna, A., Ilarslan, R. and Ilarslan, H. 1997. New chromosome counts in the subtribe Centaureinae (Asteraceae, Cardueae) from West Asia. Bot J Linn Soc125: 343-349.

Gower, J.C. 1971. A general coefficient of similarity and some of its properties. Biometrics27: 857-871.

Halbritter, H., Ulrich, S., Grimsson, F., Weber, M., Zetter, R., Hesse, M., Buchner, R., Svojtka, M. and Frosch-Radivo, A. 2018. Illustrated pollen terminology. Second edition. Springer.

Hayta, S., Tasar, N., Kiran, Y. and Baser, B. 2017. Comparative morphological, karyological and palynological investigations of three endemic Centaurea L. species (Asteraceae) in Turkey. Botany Letters 164: 241-251.

Hoffmann, O. 1890-94. Compositae. In:Engler, A. and Prantl, K. (Eds.),Die natürlichen Pflanzenfamilien. Leipzig. pp. 87-387.

Kaya, Z. 1986. Exterior and interior morphological studies on the Turkish endemic Centaurea derderiifolia Wagenitz and Centaurea saligna (C. Koch) Wagenitz. J. Res. Pharm. 2: 145-156.

McNeill, J. 1979. Purposeful phenetics. Systematic Zoology 28: 465-482.

Mesfin, T., Crawford, D.J. and Smith, E.B. 1995. Pollen morphology of North American Coreopsis (Compositae-Heliantheae). Grana 34: 21-27.

Ozler, H., Kaya, Z. and Pehlivan, S. 2009. Pollen morphology of some Centaurea L., Psephellus Cass. and Cyanus Miller taxa. Acta Biol Cracov Bot51: 53-66.

Pehlivan, S. 1995. Pollen morphology of some Turkish endemic Centaurea. Grana 34: 29-38.

Pınar, M.N., Coşkunçelebi, K., Şimşek, D., Okur, S., Makbul, S. and Acar, A. 2016. Pollen morphology of Scorzonera (Asteraceae) in Turkey. Phytotaxa 252: 233-262.

Punt, W. and Hoen, P.P. 2009. The Northwest European Pollen Flora, 70: Asteraceae-Asteroideae. Rev Palaeobot Palyno157: 22-183.

Punt, W., Hoen, P.P., Blackmore, S., Nilsson, S. and Le Thomas, A. 2007. Glossary of pollen and spore terminology. Rev Palaeobot Palyno143: 1-81.

Romaschenko, K., Ertuğrul, K., Susanna, A., Garcia-Jacas, N., Uysal, T. and Arslan, E. 2004. New chromosome counts in the Centaurea Jacea group (Asteraceae, Cardueae) and some related taxa. Bot J Linn Soc 145: 345-352.

Sirin, E., Çeçen, Ö., Bozkurt, M. and Ertuğrul, K. 2019. Centaurea uysalii (Cyanus/Asteraceae), a new species from Turkey. Turk J Bot 43: 809-816.

Sneath, P.H. and Sokal, R.R. 1973. Numerical taxonomy. The principles and practice of numerical classification, San Francisco, CA, USA.

Sokal, R.R. and Rohlf, F.J. 1962. The comparison of dendrograms by objective methods. Taxon11: 33-40.

Stix, E. 1960. Pollenmorphologische untersuchungen an Compositen. Grana 2: 41-104.

Susanna, A. and Garcia-Jacas, N. 2007. Tribe Cardueae Cass.In:Kadereit, J.W.and Jeffrey,C. (Eds.),Kubitzki's The families and genera of vascular plants. pp. 123-147.

Uysal, T. 2012. Centaurea L. In: Guner A., Aslan,S., Ekim,T., Vural, M. and Babac, M.T. A Checklist of the Flora of Turkey (Vascular Plants). Nezahat Gokyigit Botanik Bahcesive Flora Arastırmaları Dernegi Yayını, Istanbul.

Uysal, T., Demirelma, H., Ertuğrul, K., Garcia-Jacas, N. and Susanna, A. 2007. Centaurea glabro-auriculata (Asteraceae), a new species from Turkey. Ann Bot Fenn 44: 219-222. 
Uysal, T., Ertuğrul, K., Susanna, A. and Garcia-Jacas, N. 2009. New chromosome counts in the genus Centaurea (Asteraceae) from Turkey. Bot J Linn Soc 159: 280-286.

Uysal, T., Özel, E., Ertuğrul, K. and Bozkurt, M. 2012. Determination of genetic relationship among Cheirolepis (Centaurea/Asteraceae) section and its relatives in Turkey. RJB 2: 104-109.

Uysal, T., Bozkurt, M., Sezer, E.N.S., Ertuğrul, K. and Tugay, O. 2015. Karyological studies of four endemic Centaurea L. species. Caryologia 68: 339-346.Uysal, T., Hamzaoğlu, E., Ertuğrul, K. and Bozkurt, M. 2016. A New Species of Centaurea (Asteraceae) From Turkey. Phytotaxa 275: 149-158.

Uysal, T. and Hamzaoğlu, E. 2017. A new Centaurea L.(Asteraceae) species from Turkey. Plant Biosystems 151: 813-821.

Uysal, T., Dural, H. and Tugay, O. 2017. Centaurea sakariyaensis (Asteraceae), a new species from Turkey. Plant Biosystems 151: 126-130.

Uzunhisarcikli, M.E., Doğan, E. and Duman, H. 2007. A new species of Centaurea L. (Cardueae: Asteraceae) from Turkey. Bot J Linn Soc 153: 61-66.

Van der Pluym, A. and Hideux, M.J. 1977. Application d'une méthodologie quantitative à la palynologie d'Eryngium maritimum (Umbelliferae). Plant Syst Evol 127: 55-85.

Wagenitz, G. 1955. Pollenmorphologie und Systematik in der Gattung Centaurea L. s. 1. Flora 142: 213-279.

Wagenitz, G. 1975. Centaurea L. In: P.H. Davis (Ed.), Flora of Turkey and the East Aegean Islands. Edinburg. pp. 513-518.

Wagenitz, G. 1976. Systematics and phylogeny of the Compositae (Asteraceae). Plant Syst Evol 125: 29-46.

Ward, J.M. 1993. Systematics of New Zealand Inuleae (Compositae-Asteraceae) - 2 A numerical phenetic study of Raoulia in relation to allied genera.New Zeal J. Bot. 31: $29-42$.

Wodehouse, R.P. 1935. Pollen grains. New York: McGraw-Hill press, 439 pp.

(Manuscript received on 3 April, 2019; revised on 8 December, 2019) 